\title{
Optimization of technological parameters of the ultrasonic extraction process when producing functional purpose drinks
}

\author{
Marina Manukovskaya, Irina Shchetilina*, and Yulia Pisklyukova \\ Voronezh State University of Engineering Technologies, 19, Revolution Avenue, Voronezh, 394036, \\ Russian Federation
}

\begin{abstract}
In this experimental work, the method of ultrasonic extraction was used to intensify the preparation of the extract. The maximum extraction of nutrients during the preparation of extracts with the maximum preserved initial bio-corrective effect on the body is possible with the help of ultrasonic extraction. The article presents experimental data on the determination of the content of macronutrients in the obtained drinks, such as potassium, sodium, calcium, magnesium, which, in comparison with other nutrients, are the most stable during the production and storage of drinks. As a result of experimental studies, it was found that, in comparison with control samples, the content of macronutrients in drinks prepared using the ultrasonic extraction method increases by $45 \%$, which makes up the body's daily need for these nutrients from $3 \%$ to $25 \%$. In drinks prepared using ultrasonic extraction, the vitamin $\mathrm{C}$ content increases by $50 \%$, and meets the daily requirement by $100 \%$. The values of antioxidant activity in samples prepared using the method of ultrasonic extraction exceed the control samples by $45-50 \%$. The studies carried out prove the high biological value of beverages.
\end{abstract}

\section{Introduction}

Organization of nutrition, taking into account the replenishment of the body's needs in the main essential substances, macro- and microelements is an urgent task of the modern food industry. The solution to this problem is possible with the maximum full use of the available raw materials and their bio-correcting potential, which is significantly reduced in the technological process due to thermal, mechanical, and chemical influences [1].

Today, the methods of ultrasound exposure are defined by the world scientific community as a particularly promising technology for the food industry as a whole. The ultrasonic technique accelerates the process of extracting biologically active substances from raw materials, which contributes to the achievement of a certain technological effect $[2,3]$.

The aim of the work is to use the method of ultrasonic extraction in the preparation of beverages with functionally directed actions.

\footnotetext{
*Corresponding author: irina.shchetilina@mail.ru
} 


\section{Material and methods}

An extractor with an ultrasonic submersible emitter was used as an experimental setup. The essence of its work is as follows: a mixture of an extractant and a plant substrate in various ratios was loaded into a container with a radiator, after which an ultrasonic generator was turned on. Oscillations of the ultrasonic frequency $(22 \mathrm{kHz})$ excited high-frequency mechanical vibrations, under the influence of which zones of intense cavitation and diffuse dissolution of cellular substrates in the extractant were formed in the processed mixture.

Ultrasonic extraction technology assumes short-term contact of berries and extractant (up to 15 minutes) when ultrasonic vibrations are applied. With an increase in the exposure time, the yield of biologically active substances increases until an equilibrium state is reached, corresponding to the most complete depletion of raw materials. This leads to a significant acceleration of the process of transition of active components from raw materials to an extractant and obtaining a product with improved physicochemical, organoleptic characteristics, as well as with a higher antioxidant activity [4].

The main characteristics of a food product are its nutritional and biological value. The biological value of a food product is a set of features of the chemical composition of a food product, determined by the content of essential amino acids, micro- and macronutrients, and vitamins [5-7].

\section{Results and discussion}

The content of macronutrients, such as potassium, sodium, calcium, magnesium, was determined in the obtained beverages, which, in comparison with other nutrients, are the most stable during the production and storage of beverages (Figure 1-6, Table 1). These studies were carried out in the accredited laboratory centers of ANO «STC Kombikorm» and LLC «Micronutrients» (Table 2).

Due to the presence of potassium, drinks help to normalize the activity of the heart muscles, activate enzymes, regulate the acid-base state of the body and water-salt metabolism, increase efficiency, maintain acid-base balance in the body, stimulate digestion, and normalize the work of the cardiovascular system [8].

Calcium is actively involved in metabolism, maintains the health of the tissues of the nervous and skeletal systems, and takes an active part in the production of necessary hormones.

Magnesium affects the absorption of calcium and B vitamins, plays an important role in the metabolism of sodium, potassium, phosphorus and vitamin C, participates in the metabolism of proteins, carbohydrates and energy metabolism, improves respiratory function, improves the functioning of the digestive system, has a positive effect on the state of the reproductive system.

Sodium contributes to the preservation of calcium and other minerals in the blood in a dissolved form, maintains the acid-base balance in the body, stimulates digestion, ensures the functioning of the urinary system, and the normal functioning of the cardiovascular system. 
Table 1. Content of macronutrients in drinks.

\begin{tabular}{|c|c|c|c|c|}
\hline \multirow{2}{*}{$\begin{array}{c}\text { Sample name } \\
\text { (drink) }\end{array}$} & \multicolumn{2}{|c|}{ Macronutrient content $(\mathbf{m g} / \mathbf{l})$} & \multicolumn{2}{c|}{ \% from the daily requirement } \\
\cline { 2 - 5 } Cheerfulness & Control & Experience & Control & Experience \\
\hline & $\mathrm{K}-340 ;$ & $\mathrm{K}-531 ;$ & $\mathrm{K}-13,2 ;$ & $\mathrm{K}-22,5 ;$ \\
& $\mathrm{Na}-12 ;$ & $\mathrm{Na}-34 ;$ & $\mathrm{Na}-0,92 ;$ & $\mathrm{Na}-3,2 ;$ \\
& $\mathrm{Ca}-75 ;$ & $\mathrm{Ca}-98 ;$ & $\mathrm{Ca}-7,3 ;$ & $\mathrm{Ca}-0,5 ;$ \\
& $\mathrm{Mg}-29$ & $\mathrm{Mg}-40$ & $\mathrm{Mg}-6,8$ & $\mathrm{Mg}-11,6$ \\
\hline \multirow{5}{*}{ Berry fresh } & $\mathrm{K}-368,4$ & $\mathrm{~K}-624,61 ;$ & $\mathrm{K}-14,7 ;$ & $\mathrm{K}-25 ;$ \\
& $\mathrm{Na}-10,8$ & $\mathrm{Na}-28,5$ & $\mathrm{Na}-, 83 ;$ & $\mathrm{Na}-2,2 ;$ \\
& $\mathrm{Ca}-32,2 ;$ & $\mathrm{Ca}-154,84 ;$ & $\mathrm{Ca}-3,22 ;$ & $\mathrm{Ca}-15,5 ;$ \\
& $\mathrm{Mg}-27,4$ & $\mathrm{Mg}-45,87$ & $\mathrm{Mg}-6,8$ & $\mathrm{Mg}-1,5$ \\
\hline \multirow{3}{*}{ Blackcurrant } & $\mathrm{K}-509,3 ;$ & $\mathrm{K}-12 ;$ & $\mathrm{K}-20 ;$ \\
with beets & $\mathrm{K}-305,4 ;$ & $\mathrm{Na}-65,2 ;$ & $\mathrm{Na}-1,7 ;$ & $\mathrm{Na}-5 ;$ \\
& $\mathrm{Na}-22,1$ & $\mathrm{Ca}-69,4 ;$ & $\mathrm{Ca}-1,23 ;$ & $\mathrm{Ca}-7 ;$ \\
& $\mathrm{Ca}-12,3 ;$ & $\mathrm{Mg}-48$ & $\mathrm{Mg}-2,34$ & $\mathrm{Mg}-12$ \\
\hline \multirow{5}{*}{ Tonus } & $\mathrm{Mg}-9,36$ & $\mathrm{~K}-256,98 ;$ & $\mathrm{K}-5,6 ;$ & $\mathrm{K}-10,3 ;$ \\
& $\mathrm{K}-140,6$ & $\mathrm{Na}-49,3 ;$ & $\mathrm{Na}-1,01 ;$ & $\mathrm{Na}-3,8 ;$ \\
& $\mathrm{Na}-13,2$ & $\mathrm{Ca}-119,91 ;$ & $\mathrm{Ca}-2,8 ;$ & $\mathrm{Ca}-12 ;$ \\
& $\mathrm{Ca}-28,4 ;$ & $\mathrm{Mg}-25,68$ & $\mathrm{Mg}-3,8$ & $\mathrm{Mg}-6,4$ \\
\hline \multirow{5}{*}{ Berry mix } & $\mathrm{Mg}-15,2$ & $\mathrm{~K}-579,4 ;$ & $\mathrm{K}-10,1 ;$ & $\mathrm{K}-23,2 ;$ \\
& $\mathrm{K}-253,1 ;$ & $\mathrm{Na}-30,6 ;$ & $\mathrm{Na}-1,6 ;$ & $\mathrm{Na}-2,6 ;$ \\
& $\mathrm{Na}-21,2 ;$ & $\mathrm{Ca}-132,8 ;$ & $\mathrm{Ca}-4,1 ;$ & $\mathrm{Ca}-13,4 ;$ \\
& $\mathrm{Ca}-41,1 ;$ & $\mathrm{Mg}-36,4$ & $\mathrm{Mg}-5,01$ & $\mathrm{Mg}-9,5$ \\
\hline
\end{tabular}

Table 2. Micronutrient content.

\begin{tabular}{|c|l|}
\hline Sample name (drink) & \multicolumn{1}{|c|}{ Micronutrient content $(\mu \mathrm{g} / \mathrm{g})$} \\
\hline & $\mathrm{Al}-0,237 ; \mathrm{Co}-0,015 ; \mathrm{I}-0,017 ; \mathrm{Na}-24,2 ; \mathrm{Si}-17,31 ; \mathrm{As}-0,0005 ; \mathrm{Cr}-0,04 ;$ \\
& $\mathrm{K}-143 ; \mathrm{Ni}-0.026 ; \mathrm{Sn}-0,0029 ; \mathrm{B}-0,064 ; \mathrm{Cu}-0,032 ; \mathrm{Li}-0,0033 ; \mathrm{P}-9,24 ;$ \\
Cheerfulness & $\mathrm{Sr}-0,178 ; \mathrm{Ca}-27,19 ; \mathrm{Fe}-0,567 ; \mathrm{Mg}-17,48 ; \mathrm{Pb}-0,0061 ; \mathrm{V}-0,0002 ; \mathrm{Mn}-$ \\
& 0,$331 ; \mathrm{Se}-0,013 \mathrm{Zn}-0,165$. \\
\hline
\end{tabular}

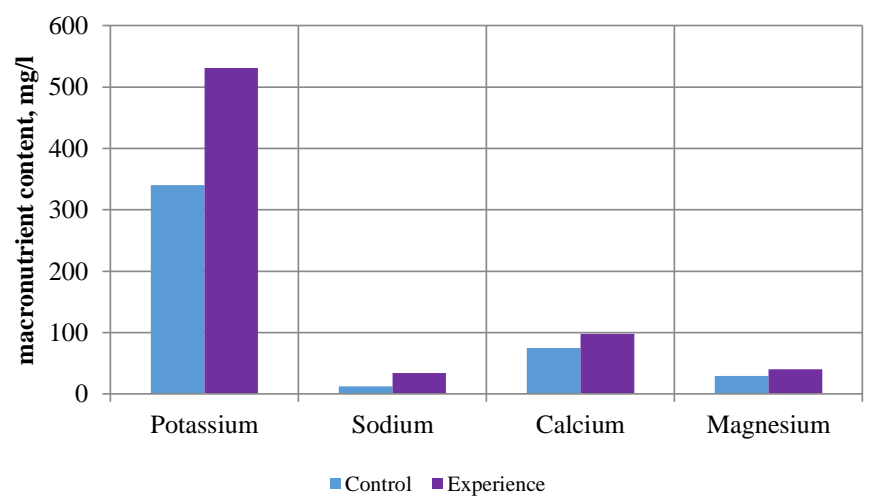

Fig. 1. The content of macronutrients in the drink «Cheerfulness». 


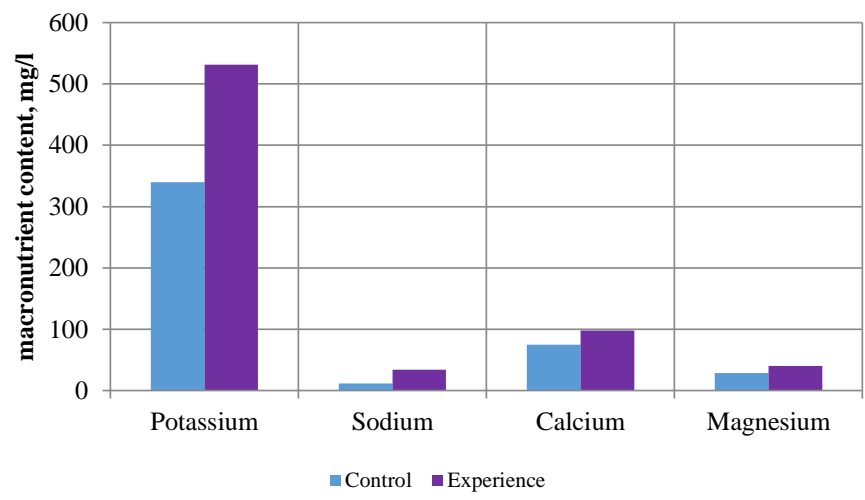

Fig. 2. The content of macronutrients in the drink « Berry fresh».

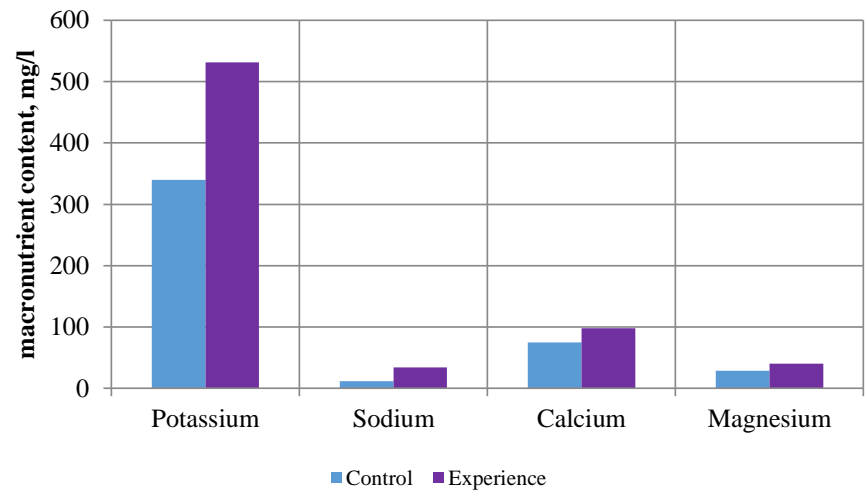

Fig. 3. The content of macronutrients in the drink «Ideal».

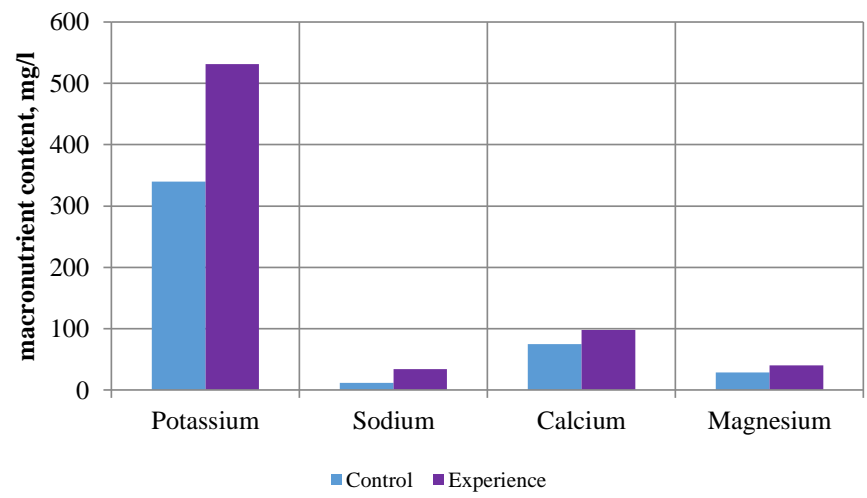

Fig. 4. The content of macronutrients in the drink «Blackcurrant with beets». 


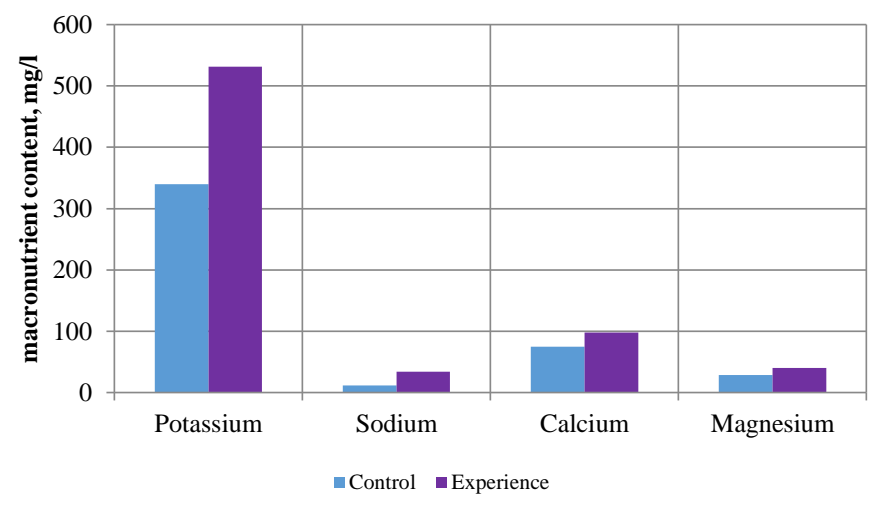

Fig. 5. The content of macronutrients in the drink «Tonus».

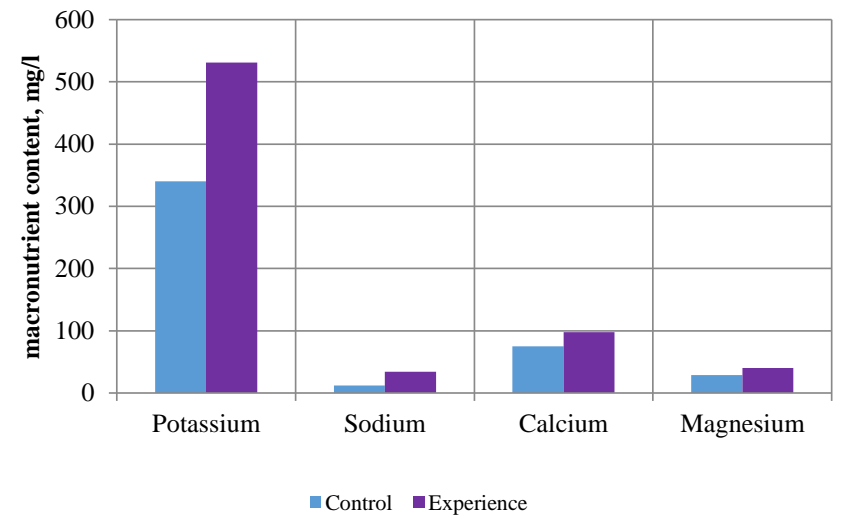

Fig. 6. The content of macronutrients in the drink «Berry Mix».

Experimental studies have shown that, in comparison with control samples, the content of macronutrients in drinks prepared using the ultrasonic extraction method increases by 45 $\%$, which replenishes the body's daily need for these nutrients from $3 \%$ to $25 \%$. This proves the intensifying effect of ultrasound, and this is also explained by the low temperature during ultrasonic extraction, which makes it possible to preserve thermolabile biologically active substances [9].

The content of vitamin $C$ in the obtained drinks was determined (Table 3, Fig. 7). Vitamin $\mathrm{C}$ is a powerful antioxidant, it participates in the processes of hematopoiesis, in the metabolic processes occurring in our body, promotes the production of collagen, increases the elasticity of skin cells, removes free radicals from the body, has a beneficial effect on the functioning of the nervous system, enhances the protective functions of the body, helps to eliminate cholesterol from blood. 
Table 3. Vitamin C content in drinks.

\begin{tabular}{|c|c|c|c|c|}
\hline \multirow{2}{*}{$\begin{array}{c}\text { Sample name } \\
\text { (drink) }\end{array}$} & \multicolumn{2}{|c|}{ Vitamin C content $(\mathbf{m g} / \mathbf{1 0 0}$ ml) } & \% from the daily requirement \\
\cline { 2 - 5 } & Control & Experience & Control & Experience \\
\hline Cheerfulness & 51,6 & 115,8 & 56 & 130 \\
\hline Berry fresh & 40,2 & 94,6 & 44,6 & 105 \\
\hline Ideal & 69,3 & 138,1 & 76 & 150 \\
\hline $\begin{array}{c}\text { Blackcurrant with } \\
\text { beets }\end{array}$ & 43,8 & 75,3 & 47 & 84 \\
\hline Tonus & 17,3 & 35,3 & 18 & 39 \\
\hline Berry mix & 52,1 & 84,2 & 53 & 93 \\
\hline
\end{tabular}

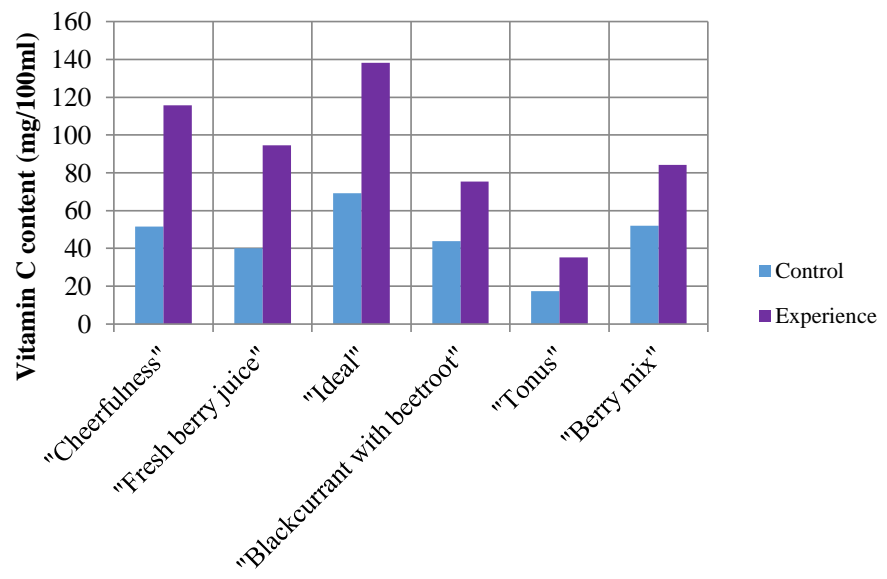

Fig. 7. Vitamin C content in drinks.

According to the results of the studies, we conclude that in drinks prepared using ultrasonic extraction, the content of vitamin $\mathrm{C}$ increases by $50 \%$, and replenishes the daily need by $100 \%$, based on this, $100 \mathrm{ml}$ of the drink can satisfy the daily need for vitamin C.

The antioxidant activity was determined in the obtained drinks (Table 4 and Fig. 8). The effect of antioxidants on the body is the ability to eliminate oxidative stress, to protect the human body at the cellular level from various influences of free radicals, to prevent the onset of oncology and to delay the aging of the body. Antioxidants can be natural or synthetic in origin. A large number of natural antioxidants are found in the following berries: black currants, cranberries, cherries, raspberries.

Table 4. The value of antioxidant activity in drinks.

\begin{tabular}{|c|c|c|}
\hline \multirow{2}{*}{ Sample name (drink) } & \multicolumn{2}{|c|}{ AOA value (mg / $\mathbf{~ d m}^{\mathbf{3}}$ ) } \\
\cline { 2 - 3 } & Control & Experience \\
\hline Cheerfulness & 57,8 & 102 \\
\hline Berry fresh & 37,4 & 62,4 \\
\hline Ideal & 42,1 & 73,6 \\
\hline Blackcurrant with beets & 53,9 & 114 \\
\hline Tonus & 49,2 & 70,5 \\
\hline Berry mix & 30,1 & 54,2 \\
\hline
\end{tabular}




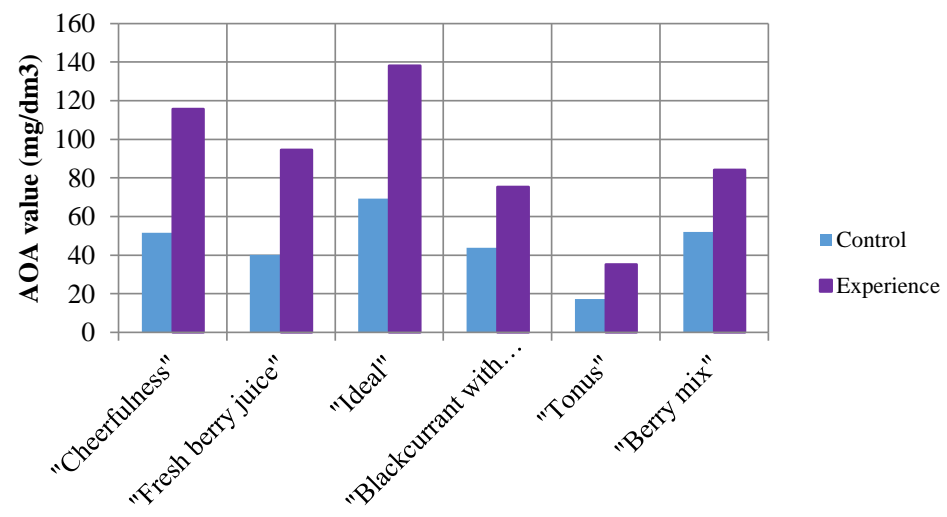

Fig. 8. The value of AOA in drinks.

\section{Conclusions}

The results obtained indicate higher values of this indicator when using ultrasonic exposure in the extraction process, which is a confirmation of the preservation of biologically active substances of natural raw materials and a corresponding increase in the functional properties of drinks based on it. The values of antioxidant activity in samples prepared using the method of ultrasonic extraction exceed the control samples by $45-50 \%$. The studies carried out prove the high biological value of beverages [10].

\section{References}

1. S. Owen, Source of power, SPb.: The amphora. Tempora (2012)

2. R. G. Jepson et al. Cranberries for preventing urinary tract infections. Cochrane Database Syst Rev., 10 (2012)

3. N. P. Seeram et al. Total cranberry extract versus its phytochemical constituents: antiproliferative and synergistic effects against human tumor cell lines. Journal of agricultural and food chemistry, 9, (2004)

4. R. I. Fatkullin, Prospects for the use of ultrasonic exposure as a factor in the formation of consumer properties of drinks on natural raw materials. Bulletin of the South Ural State University. Series: Economics and Management, 4 (2013)

5. I. M. Skurikhin, Chemical composition of food products. Deliprint (2002)

6. N. V. Sudakova, N. V. Koeva, N. P. Oboturova, The use of ultrasound in obtaining extracts and infusions from vegetable raw materials. Modern scientific research and innovations, 11 (2013)

7. I. P. Shchetilina, Analysis of consumer preferences of residents of Voronezh in relation to functional products from fruit and berry raw materials. Bulletin of the Voronezh State University of Engineering Technologies, 68, (2016)

8. N. S. Rodionova, M. V. Manukovskaya, A. E. Nebolsin, M. V. Serchenya, Application of the method of ultrasonic extraction in the preparation of a directed-action drink from black curran.t berries, Bulletin of Voronezh State University of Engineering Technology, 68, (2016) 
9. A. V. Rocky, Z. G. Ordzhonikidze, O. A. Gromova, Macro and trace elements in physical culture and sports, M.: KMK, (2000)

10. M. V. Manukovskaya, I. P. Shchetilina, A. G. Kudryakova, S. R. Kozlova, A. O. Torosyan, A. V. Gorbunov, Development of beverage recipes with specified biocorrective properties based on plant raw materials using the method of ultrasonic extraction. Bulletin of the Voronezh State University of Engineering Technologies, 82, (2020) 